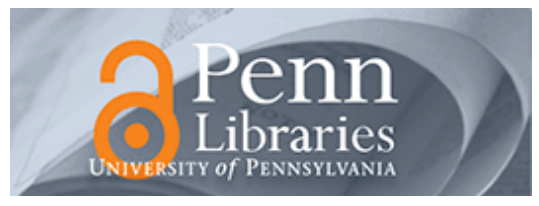

University of Pennsylvania

ScholarlyCommons

Marketing Papers

Wharton Faculty Research

2005

\title{
The Film Exhibition Business: Critical Issues, Practice, and Research
}

Jehoshua Eliashberg

University of Pennsylvania

Follow this and additional works at: https://repository.upenn.edu/marketing_papers

Part of the Advertising and Promotion Management Commons, Marketing Commons, Operations and Supply Chain Management Commons, and the Other Economics Commons

Recommended Citation (OVERRIDE)

Eliashberg, J. (2005). The Film Exhibition Business: Critical Issues, Practice, and Research. In Moul, C.C. (Ed.), A Concise Handbook of Movie Industry Economics, 138-162. Cambridge University Press.

This paper is posted at ScholarlyCommons. https://repository.upenn.edu/marketing_papers/404

For more information, please contact repository@pobox.upenn.edu. 


\title{
The Film Exhibition Business: Critical Issues, Practice, and Research
}

\author{
Abstract \\ The supply chain for movies released for theatrical exhibition consists of the distributor, exhibitor, and the \\ audience, as shown in Figure 5.1. The audience has opportunities to watch moveis in a number of \\ distribution outlets: domestic theaters, foreign theaters, home video, and cable and network TV, where the \\ time lags between the releases of the movies in successive outlets differ but are typically measured in \\ months (Figure 5.2). Despite the availability of these multiple release windows, the theatrical performance \\ of films in the United States has been considered by practitioners to be a critical success driver. \\ "Theatrical exhibition is the major factor in persuading the public what they want to see, even if that public \\ never sets foot inside a motion picture theater. And how well and how long a picture plays in theaters has \\ everything to do with its value in other markets" (Daniels, Leedy, and Sills 1998, p. 34). the main reasons \\ as to why the theatrical experience is believed to have such a significant impact on the performance of \\ the movie in its other distribution channels are the buzz created by the studios prior to and during the \\ theatrical release dates, generated through high advertising spending, and the attention given by the \\ media to box-office performance and figures.

\section{Disciplines} \\ Advertising and Promotion Management | Business | Marketing | Operations and Supply Chain \\ Management | Other Economics
}




\title{
The Film Exhibition Business: Critical \\ Issues, Practice, and Research
}

\author{
JEHOSHUA ELIASHBERG
}

The supply chain for movies released for theatrical exhibition consists of the distributor, exhibitor, and the audience, as shown in Figure 5.1. The audience has opportunities to watch movies in a number of distribution outlets: domestic theaters, foreign theaters, home video, and cable and network TV, where the time lags between the releases of the movies in successive outlets differ but are typically measured in months (Figure 5.2). Despite the availability of these multiple release windows, the theatrical performance of films in the United States has been considered by practitioners to be a critical success driver: Theatrical exhibition is the major factor in persuading the public what they want to see, even if that public never sets foot inside a motion picture theater. And how well and how long a picture plays in theaters has everything to do with its value in other markets" (Daniels, Leedy, and Sills 1998, p. 34). The main reasons as to why the theatrical experience is believed to have such a significant impact on the performance of the movie in its other distribution channels are the buzz created by the studios prior to and during the theatrical release dates, generated through high advertising spending, and the attention given by the media to box-office performance and figures. It is interesting to note that the recent phenomenon characterized as 


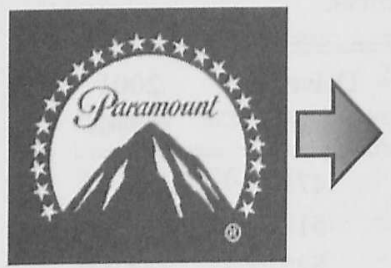

Distributor

(e.g.,Paramount)

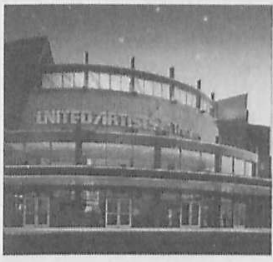

Exhibitor

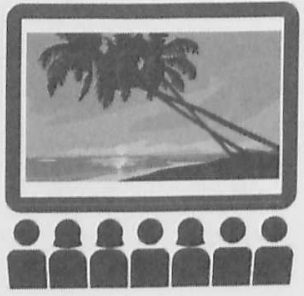

Audience

\section{(e.g., Regal Entertainment)}

Figure 5.1: Industry structure (the supply chain).

"TV screens get larger and movie theater screens get smaller" has, to date, not had a significant negative impact on the moviegoers' behavior. Watching movies in theater still offers the audience a different experience.

New improvements in theatrical facilities, such as the availability of multiple screens, more comfortable environment, improved sound and picture presentations, and the offering of a range of ancillary products, have led to a sustainable attendance level in the United States, as well as

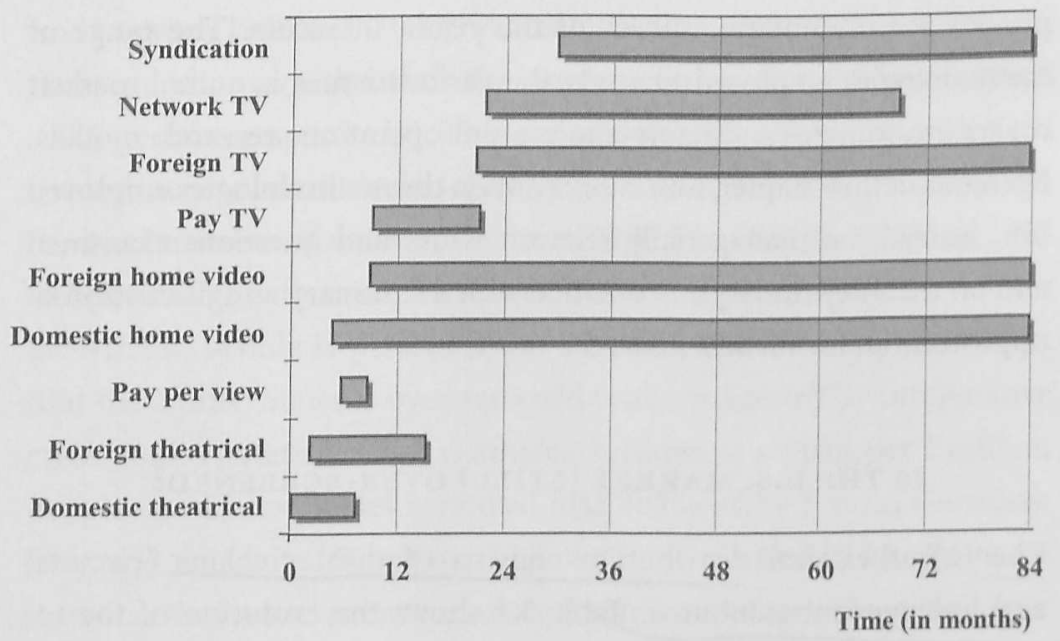

Figure 5.2: Movies' release windows. Source: Vogel (2001). 
Table 5.1: Total number of U.S. theaters.

\begin{tabular}{lcccccc}
\hline Year & $\begin{array}{c}\text { Total } \\
\text { theaters }\end{array}$ & $\begin{array}{c}2001 \\
\text { versus }\end{array}$ & $\begin{array}{c}\text { Indoor } \\
\text { theaters }\end{array}$ & $\begin{array}{c}2001 \\
\text { versus }\end{array}$ & $\begin{array}{c}\text { Drive-in } \\
\text { theaters }\end{array}$ & $\begin{array}{c}2001 \\
\text { versus }\end{array}$ \\
\hline 2001 & 7,070 & - & 6,596 & - & 474 & - \\
2000 & 7,421 & $-4.7 \%$ & 6,909 & $-4.5 \%$ & 512 & $-7.4 \%$ \\
1999 & 7,551 & $-6.4 \%$ & 7,031 & $-6.2 \%$ & 520 & $-8.8 \%$ \\
1998 & 7,418 & $-4.7 \%$ & 6,894 & $-4.3 \%$ & 524 & $-9.5 \%$ \\
1997 & 7,480 & $-5.5 \%$ & 6,903 & $-4.4 \%$ & 577 & $-17.9 \%$ \\
1996 & 7,798 & $-9.3 \%$ & 7,215 & $-8.6 \%$ & 583 & $-18.7 \%$ \\
1995 & 7,744 & $-8.7 \%$ & 7,151 & $-7.8 \%$ & 593 & $-20.1 \%$ \\
\hline
\end{tabular}

Source: MPAA Worldwide Market Research.

in large foreign markets such as the United Kingdom (Doyle 1998) and even in smaller countries such as Thailand (Towira 2000).

In this chapter, I focus on the first two theatrical release windows: domestic and foreign theaters. The chapter is organized as follows. I first review the reality of the theatrical exhibition business today, offering observations as well as conjectures concerning its future. The proposed hypotheses can be viewed as opportunities for formal research. Some of them have already received research attention - others have not. I provide a representative survey of the extant literature. The range of methodologies employed to study the various issues is quite broad. It covers econometrics, discrete-choice, and operations research models. My focus in this chapter, however, is not on the methodologies employed but, instead, on managerially relevant issues and questions examined and on their key findings. I conclude with a summary and discussion of opportunities for further research.

\section{IS THE U.S. MARKET (STILL) OVER-SCREENED?}

The U.S. theatrical distribution consists of theater chains (circuits) and independent exhibitors. Table 5.1 shows the evolution of the total number of U.S. theaters operating in 2001 and Table 5.2 depicts the 
The Film Exhibition Business: Critical Issues, Practice, and Research

Table 5.2: Total number of U.S. screens.

\begin{tabular}{lcccccc}
\hline \hline Year & $\begin{array}{c}\text { Total } \\
\text { screens }\end{array}$ & $\begin{array}{c}2001 \\
\text { versus }\end{array}$ & $\begin{array}{c}\text { Indoor } \\
\text { screens }\end{array}$ & $\begin{array}{c}2001 \\
\text { versus }\end{array}$ & $\begin{array}{c}\text { Drive-in } \\
\text { screens }\end{array}$ & $\begin{array}{c}2001 \\
\text { versus }\end{array}$ \\
\hline 2001 & 36,764 & - & 36,110 & - & 654 & - \\
2000 & 37,396 & $-1.7 \%$ & 36,679 & $-1.6 \%$ & 717 & $-8.8 \%$ \\
1999 & 37,185 & $-1.1 \%$ & 36,448 & $-0.9 \%$ & 737 & $-11.3 \%$ \\
1998 & 34,186 & $7.5 \%$ & 33,440 & $8.0 \%$ & 746 & $-12.3 \%$ \\
1997 & 31,640 & $16.2 \%$ & 30,825 & $17.1 \%$ & 815 & $-19.8 \%$ \\
1996 & 29,690 & $23.8 \%$ & 28,864 & $25.1 \%$ & 826 & $-20.8 \%$ \\
1995 & 27,805 & $32.2 \%$ & 26,958 & $33.9 \%$ & 847 & $-22.8 \%$ \\
1990 & 23,689 & $55.2 \%$ & 22,774 & $58.6 \%$ & 915 & $-28.5 \%$ \\
1985 & 21,147 & $73.8 \%$ & 18,327 & $97.0 \%$ & 2,820 & $-76.8 \%$ \\
1980 & 17,590 & $109.0 \%$ & 14,029 & $157.4 \%$ & 3,561 & $-81.6 \%$ \\
\hline
\end{tabular}

Source: MPAA Worldwide Market Research.

dynamics of the total number of screens available to the public. Jointly, the two tables suggest that the year 2000 may be considered as a turning point, the year when the exhibition industry started a trend of downward adjustment of the total number of screens available in the U.S. The growth rates in the total number of screens between 1997 and 1998 (8 percent) and between 1998 and 1999 ( 9 percent), for example, are higher than the corresponding growth rates in the number of admissions (6.5 percent and -0.6 percent, respectively). This gap may have been one factor that led the industry to conclude that the U.S. market is over-screened. Although the total number of screens rose from 22,921 in 1989 to 37,185 in 1999 (62 percent growth rate), the number of admissions has shown a lower growth rate of only 17 percent (from 1.26 billion to 1.47 billion). The fact that the United States is over-screened is also suggested by comparative cross-country statistics. For example, considering screens per 1 million people, the United States is ranked first, followed by France, Germany, Italy, and the United Kingdom (Figure 5.3). In the United Kingdom, for instance, the annual growth of cinema screens has been more moderate compared with the United States (see Table 5.3). 
Jehoshua Eliashberg

Table 5.3: The UK motion picture industry (1995-2002)

\begin{tabular}{lrrrrrrrr}
\hline \hline & 1995 & 1996 & 1997 & 1998 & 1999 & 2000 & 2001 & 2002 \\
\hline Admissions (million) & 115 & 124 & 139 & 136 & 140 & 143 & 156 & 176 \\
Cinema sites & 743 & 742 & 747 & 759 & 692 & 686 & 692 & 668 \\
Cinema screens & 2,019 & 2,166 & 2,383 & 2,564 & 2,758 & 2,954 & 3,614 & 3,258 \\
Multiplex sites & 79 & 95 & 142 & 167 & 186 & 209 & 224 & 222 \\
Multiplex screens & 706 & 859 & 1,222 & 1,488 & 1,727 & 2,003 & 2,170 & 2,215 \\
Average ticket price (£) & 3.43 & 2.81 & 3.68 & 3.83 & 3.80 & 4.00 & 4.14 & 4.29 \\
Box office gross (£M) & 384 & 426 & 506 & 515 & 571 & 577 & 652 & 755 \\
\hline
\end{tabular}

Source: British Film Institute (2004).

Davis (2003b), however, claims that distinguishing between first-run and second-run theaters shows that the growth in domestic first-run screens has been far less than what is implied by the raw gross screen count. He examines a panel data set documenting the extent and nature of exit, entry, and revenue cannibalization that occurred during the $1990 \mathrm{~s}$ in the U.S. exhibition sector. Although an exact answer to the question of social over-screening requires as-yet uncalculated measures of consumer surplus and cost, this study indicates that a substantial portion of a new theater's demand is "stolen" from existing theaters rather than composed

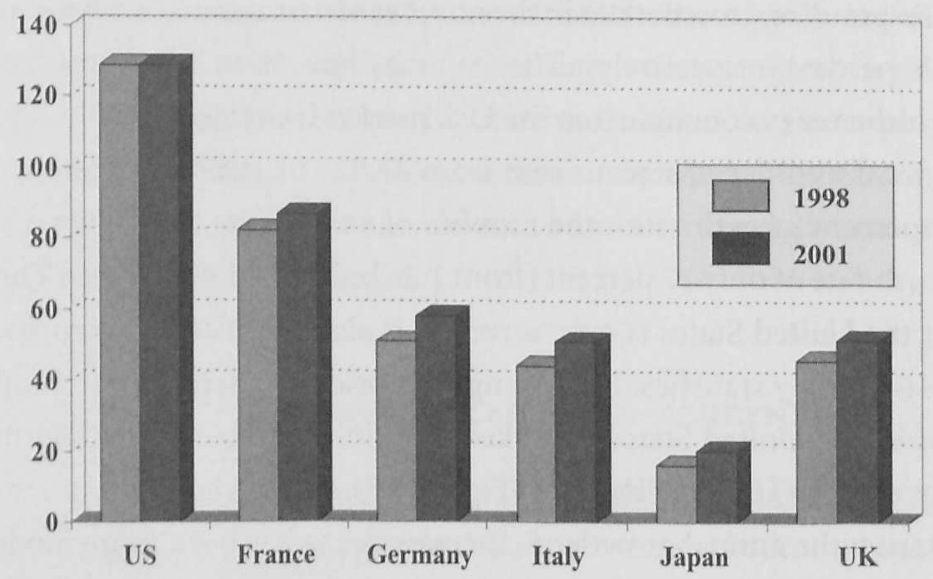

Figure 5.3: Screens per 1 million people. Source: EAO (2002). 
The Film Exhibition Business: Critical Issues, Practice, and Research

of new consumers. Because such business stealing is a necessary condition for the over-screening argument, the question remains open. He is able, however, to use Canadian theater data to argue that the sector is overscreened from an industry profit-maximizing viewpoint.

THE MARKET WILL BECOME MORE CONCENTRATED: MORE EXPANSION AND HORIZONTAL INTEGRATIONS (MERGERS AND ACQUISITIONS) ARE LIKELY TO OCCUR, AND THE PLAYERS WILL BE DIFFERENT

The exhibition industry has been undergoing major structural changes recently. Two snapshots of the industry demonstrate those changes. As of May 1, 1994, the exhibition chains United Artist Theaters, Carmike Cinemas, Cineplex Odeon, AMC Entertainment, and General Cinema Theaters owned a total of 8,473 screens, which amounted then to 33 percent of the total U.S. screens. By comparison, in the United Kingdom, in 1998 the leading five exhibitors (for example, Odeon, UCI, and Virgin Cinemas) accounted for more than 60 percent of the total screens. Given this discrepancy, it is not surprising that concentration in the U.S. exhibition market has risen in recent years. This prognosis, however, might be questioned by those who note the fairly stable number of films released in the United States annually by the studios (Figure 5.4). It is conceivable that more movies may have been produced and were looking for exhibition opportunities, but the exceedingly high average print and advertising expenditures necessary to support their theatrical distribution ( $\$ 31$ million on average in 2002) prohibit the distributors from releasing them. In such a case, the supply of movies has been less than the "shelf-space" available to play them.

At present, the U.S. exhibition landscape looks quite different from 1994. The top five exhibition chains in 2003 were Regal Entertainment Group with 5,850 screens in 552 sites, AMC Entertainment with 3,308 screens in 235 sites, Carmike Cinema with 2,333 screens in 323 sites, 
Jehoshua Eliashberg

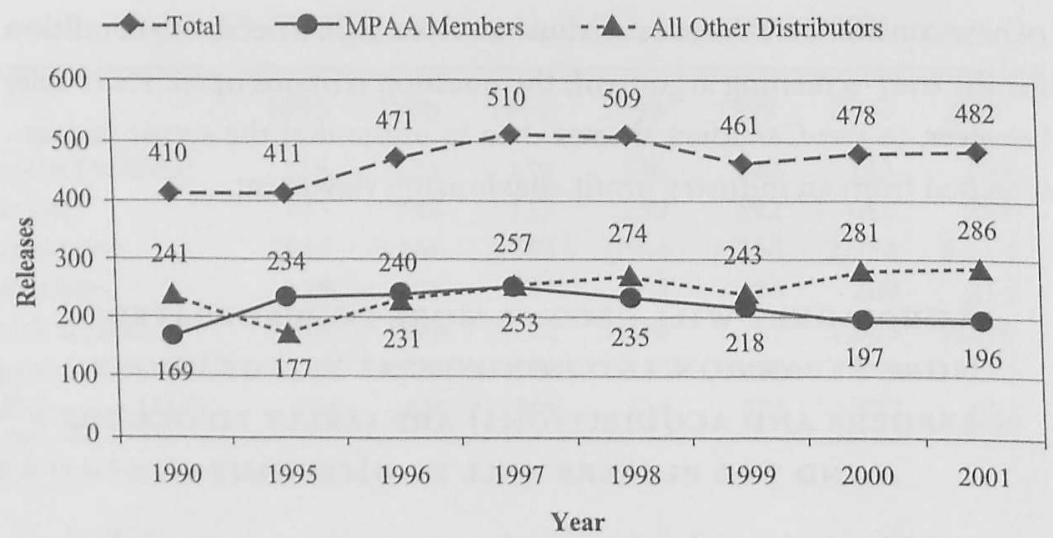

Figure 5.4: Films released in the United States. Source: MPAA Workwide Market Research.

Cinemark USA with 2,241 screens in 191 sites, and Loews Cineplex Entertainment with 2,161 screens in 226 sites. They accounted for 44.6 percent of the total number of screens and 25 percent of the total number of sites. (Note that seats per screen have declined over time.) In fact, just recently, Regal Entertainment announced that it would purchase half of Hoyts Cinemas' U.S. theaters (fifty-two of Hoyts' ninty-two theaters), thus extending its reach into the Northeast market. Regal Entertainment, under the leadership of Philip Anschuts, will expand its reach to 6,100 screens by next year. The Denver-based company reported that 2002 "was a blockbuster year for Regal” (Diorio 2003). Annual revenue climbed 13 percent to $\$ 2.27$ billion.

Niche players will also play an increasingly important role in the industry in the future. For example, GameWorks, a Los Angeles-based chain of arcade/restaurants, has announced a $\$ 20$ million project in Oklahoma City to build a multiplex with "GameWorks elements" including games, a restaurant, bars, and bowling (Emmons 2001). Muvico Theaters, a Florida-based exhibitor founded in 1984, now owns 104 screens. It pursues an expansion strategy "to develop, acquire and operate stateof-the-art megaplex theaters in entertainment centers in mid-sized 
metropolitan markets and suburban growth areas of larger metropolitan markets in any suitable location." Indeed, exhibition circuits tend to operate in certain regions as local monopolists and sometime duopolists (for instance, Carmike operates in small cities where it faces little competition). In Birmingham, Alabama, for example, the theater exhibition is almost evenly divided between two chains: Regal Cinemas with fifty-two screens and Carmike with forty-eight screens, "resulting in moviegoers being offered a very limited range of films, forcing adventurous viewers to travel to other cities or wait half a year for video releases" (Brasell 1999).

Since the mandated separation of distribution and exhibition in 1948, integration in the exhibition sector has been horizontal rather than vertical. ${ }^{1}$ Horizontal integration has occurred through new real estate selection and development as well as mergers and acquisitions. Market expansion via new sites selection is one of exhibitors' key strategic decisions. The local population is typically the most important factor. The age demographics and, to some extent, economics of local consumers play the substantial roles. A rule of thumb employed by some practicing executives is one screen for every ten thousand people with estimated attendance of 5.5 movies per year per person. Based on such a heuristics and assuming an even exogenous arrival distribution (ten thousand moviegoers per 2.182 months) and thirty-six key showings per month ( 4 weekends $\times 3$ days per weekend $\times 3$ showings per day), the seating capacity needed to accommodate the audience is 127 seats per screening $\operatorname{room}(10,000 /(2.182 \times 36))$.

Cross-sectional demand results in Davis (2001) suggest that consumers are generally unwilling to travel and, consequently, theaters may be close to local monopolies. Given this market power, local markets may underprovide movie screens relative to the socially optimal number.

1 In that year, a suit that was previously filed by the U.S. Department of Justice concluded with the "Paramount decrees," which prohibited the distributors from vertical integration. Since the 1980 s, however, the regulation has been relaxed by allowing a number of distributors (e.g., Sony, Paramount, and Warner Brothers) to have exhibition interests as long as their percentage of the total number of screens remains low. 
Davis (2003a) uses the same data to examine the issue of price differentiation across geographic markets, as well as the relationship between local competition and admission prices. He finds that "the effect of the presence of local competition on adult admission prices, though often highly statistically significant, is economically relatively small unless the theaters are very close to one another" (p. 23). Hence, concerns regarding a possible rise in admission prices as a result of the recent mergers and acquisitions wave are not supported by his analysis. Although these papers each make useful methodological contributions, their conclusions contradict those of Davis (2003b), where business-stealing is common. This difference probably arises from the use of cross-sectional data in Davis (2001, 2003a) and panel data in Davis (2003b). Given the additional variation typically associated with panel data, the results of Davis (2003b) are likely more credible.

\section{THE CONTRACTUAL ARRANGEMENT BETWEEN THE DISTRIBUTOR AND THE EXHIBITOR WILL CHANGE}

The decision to negotiate directly with theaters or to solicit bids is a business judgment made by the distributor. Most contractual arrangements between the distributor and the exhibitor stipulate a minimum playing time and an agreement as to how the box-office receipts are to be shared between the two parties. For many major movies, a sliding-scale agreement is used. Exhibitors pay the largest of the amounts implied by the three following possibilities. The primary term is the rental rate, setting what percentage of total admissions receipts the exhibitor will cede to the distributor. These rental rates vary across movies, across theaters, and across weeks for a given movie at a given theater. Rates typically fall from 60 or 70 percent in a movie's opening week to 30 percent in the movie's final weeks, but substantial deviations from this baseline are common.

Contracts have two additional components: (1) an after-house allowance ("nut") split (usually 90 percent to the distributor), and (2) a 
floor. 'The nut is based on theater capacity and is recognition, on the distributor's part, that the exhibitor incurs expenses in running the facility (for example, rent, insurance, maintenance). The floor serves as a guaranteed minimum for the distributor. Of course, the specific values of the split, floor, and rental rate are determined by the relative power of the two parties. The key power bases are the relative shortage (surplus) of screens, the total number of screens the exhibitor owns, and the potential success of the movie to be shown. Whereas the exhibitor's share of the ticket sales increases as the movie is playing for a longer period of time, the downside is that the distributor normally stops the advertising/promotion support after the first two or three weeks of the movie's run. This gives rise to two options the exhibitor faces: obtaining a small share from a large pie (playing a newly released movie) or a large share from a smaller pie (playing an ongoing movie longer).

Although legally the determination of the admission price is in the hands of the exhibitor, the distributor monitors it informally. The admission price raises a contracting problem: the exhibitor might prefer a lower price in order to compete more effectively with other exhibitors. Lower ticket prices may also increase attendance and, consequently, the revenues from concessions, a revenue source not shared with the distributor. 'The distributor, however, would prefer a higher ticket price (Caves 2000). Several years ago, Edgar Bronfman, then CEO of Universal, put forward an innovative but controversial ticket-pricing idea (Battaglio and Honeycutt 1998). He suggested that admission prices of movies be differentiated on bases such as production budget and star power. Morcover, Bronfman

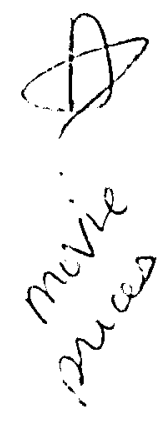
argued that the demand for movies in their opening weekend is inelastic and, hence, there may be room for temporal price discrimination. Such pricing schemes can increase the size of the pie that the distributor/ exhibitor share, thereby making both parties better off. The industry has not adopted similar price-discrimination ideas for reasons such as the absence of an agreed-upon base for across-titles pricing and the lack of coordination among exhibitors in terms of temporal price discrimination. 


\section{Jehoshua Eliashberg}

Research questions related to the issues mentioned herein include a reexamination of the current contract in terms of its timeliness and fairness and the uniformity of movie ticket prices across titles and over time. The first issue, reexamination of the contractual arrangement, raises the possibility that, until the exhibition sector sufficiently reduces capacity, implicit block-booking arrangement of films is quite likely to prevail. Block-booking involves selling motion pictures as a package. It was banned by the U.S. Supreme Court in 1962 on grounds that the practice was unfair to the exhibitor because it forced them to play movies that ex post turned out to be unsuccessful. ${ }^{2}$ Arguing against the ruling, Stigler (1968) pointed out the potentially welfare-enhancing aspects of the practice. Furthermore, in a recent study, Hanssen (2002) argues that the block-booking arrangement was not an unfair practice but instead a necessity that provided product.

The question of uniform prices across titles (successful and unsuccessful) and over time has received some attention by Einav and Orbach (2001). They identified flaws in this pricing policy and provided explanations and possible justifications for the uniform prices. The justifications include perceived price unfairness by consumers, movies' short life cycle that limits the exhibitors' opportunity to adjust prices once the uncertainty concerning the popularity of the movie is resolved, diverging exhibitors and distributors interests, and the instability of the demand.

\section{CONSUMERS WILL BECOME MORE LOYAL TO THEATER CIRCUITS AND SITES}

Consumers follow different decision-making processes in selecting what movie to watch, at what time during the day, and in what theater. Based on anecdotal evidence, one may distinguish between two behavioral processes: (1) movie first-theater next, or (2) theater first-movie next.

2 United States v. Loew's Inc., 371 U.S. 38 (1962). 
Under the former process, which is more common in the United States, the consumer first decides on the movie and then selects the most convenient site. Under the latter process, more commonly observed in foreign markets, the consumer first attends his or her favorite theater and, once there, decides on the movie.

Theater circuits in the United States are trying to induce more consumers to adopt the theater first-movie next heuristic. AMC Entertainment, for example, has a program called "MovieWatcher," which provides moviegoers various benefits including free tickets, concessions, and entertainment news. This program, which is very similar to that of other service providers such as airlines and hotels, has been designed to create loyalty to a particular theater circuit and, possibly, to a particular site. It requires proper marketing and advertising efforts by exhibitors, as well as other perks such as "after-movie mints ... and ushers who even clean the snow from windshields" to ensure that the loyalty to the theater is retained (Eller 2002). In a more rigorous work, Davis (2001) develops an econometric model of movie demand, considering theater characteristics (price and quality), as well as the distances consumers have to travel. He finds statistically significant preferences for theaters with digital projection, THX sound, and more screens. He also offers estimates of relative magnitudes. THX sound and digital projection have approximately the same effect on consumer decisions, and adding about seven additional screens generates the same effect on demand as introducing THX or digital.

\section{THE DIGITAL TECHNOLOGY: THREATS AND OPPORTUNITIES}

Technological advances in new digital technologies are likely to present threats as well as opportunities to the exhibition industry. (Chapter 2 detailed the likely benefits of digital technologies to production.) New peer-to-peer networks make sharing large electronic files such as movies faster and easier. Distribution via the Internet may affect movic-going behavior. "By the end of the year it is estimated that one million 
Table 5.4: (Illegal) distribution via the Internet: How widespread is it?

\begin{tabular}{ll}
\hline \multicolumn{2}{c}{ Media Force's Top 10 Pirated Movies List (August 2001) } \\
\hline Title & \multicolumn{1}{c}{ Distributor } \\
\hline 1. American Pie & Universal \\
2. The Fast and the Furious & Universal \\
3. Shrek & DreamWorks \\
4. Jurassic Park III & Universal \\
5. The Matrix & Warner Bros \\
6. Planet of the Apes & 20th Century Fox \\
7. Crouching Tiger, Hidden Dragon & Sony \\
8. Swordfish & Warner Bros \\
9. Traffic & USA Films \\
10. Fight Club & 20th Century Fox \\
\hline
\end{tabular}

Source: Media Force (October 2001).

illegal downloads-will-take place ery day," said Jack Valenti (MPAA press release, April 3, 2001). Table 5.4 shows the titles of the most pirated movies in 2001. It appears that the piracy increases the buzz, but at the same time leads to losses in ticket and video-sales. Distributors and studios are attempting to fight the piracy threat via simultaneous release of movies in the U.S. and foreign markets, court battles, and by educating and inducing consumers to use legal Internet distributions, such as the networks established by the studios and distributors themselves (for example, Movielink.com). Movie exhibitors, on the other hand, believe that it is unlikely that the experience of watching a movie on a computer screen will cannibalize the theatrical experience and, hence, they remain largely unconcerned with the piracy threat.

Digital cinema, which is a means of projecting a moving image without using a reel of film, is another technology on the horizon that will have impacts on several sectors of the movie business, exhibition in particular (Table 5.5). Its superiority lies in both its image and sound quality and its lack of deterioration with time and multiple showings. Its projected 
The Film Exhibition Business: Critical Issues, Practice, and Research

Table 5.5: Digital cinemas: How widespread are they?

- July 1999: Disney announces that "Tarzan," the studio's latest animation feature, will be screened electronically using Texas Instruments prototype projectors in three theatrical venues.

- February 2000: Texas Instruments brings its DLP Cinema technology to Europe, with screenings of "Toy Story 2" in Paris, Brussels, London, and Manchester, in cooperation with Technicolor's Real Image Digital.

- November 2000: Disney division Miramax premieres "Bounce" digitally in New York with satellite delivery courtesy of Boeing. Other partners arc Texas Instruments, QuVis, and AMC Theaters. Miramax had previously screened "Shakespeare in Love" and "Life Is Beautiful" using JVC's ILA e-cinema technology.

- January 2001: National Cinema Network (NCN) debuts its Digitil Theatre Distribution System (DTDS) for e-cinema advertising on 83 screens in three U.S. theaters in Anaheim (CA), Kansas City (MO), and New York (NY).

Source: Screen Digest (2001).

market penetration is debatable:

A survey conducted as part of the Celluloid of Silicon initiative reports that "a clear majority of respondents think that at least 40 percent of European screens will be digital by 2010."

(Screen Digest Report 2002, p. 43)

By 2006 we do not expect more than 1,000 screens, or less than 3\% of the country's 35,700 screens, to be digitally capable.

(PricewaterhouseCoopers 2002)

Although progress has been made in some areas ..., it has not been made in economics... With economics likely to remain a challenge, we pushed back our original 5\% penetration estimate for digital cinema screen from 2004 to 2006.

(Credit Suisse First Boston, 2002)

Its likely impact is more certain. Digital cinema will reduce the print and advertising cost of a movie to the distributor and studio, but it will require the exhibitor to invest heavily in digital projectors 
( $\$ 100,000-\$ 150,000$ per screen) and other infrastructure (for example, data storage and satellite dishes), as well as in operational and service support. If digital projection devices are adopted, they will almost certainly increase the exhibitor's house allowance in the contract but simultaneously increase the distributor's control over how the exhibitor manages the allocation of movies to screens. It will also offer a number of new opportunities: (1) higher ticket prices from offering an enhanced consumer experience; (2) alternative and flexible programming opportunities such as screening live events (for example, sports, concerts), games and interactive films, and business conferences; and (3) new advertising possibilities, probably tailored to local audiences. Regal Entertainment Group has already introduced a 20 -minute "preshow" loaded with ads before every film at its twenty-seven Philadelphia-area theaters (Hiltbrand 2003).

\section{EXHIBITION EXECUTIVES FACE A COMPLEX}

\section{STRATEGIC SPACE}

In the near future, the strategic agenda of the top management of an exhibition circuit will consist of the following decisions: new sites selection, lease negotiation, facility design, hiring and training personnel, theater marketing and pricing, capacity management via other business models, and, of course, film procurement and film scheduling (macro and micro) in the facility. The research already conducted in this area can be classified as taking one of two perspectives: the industry's or an individual exhibitor's, discussed herein.

Film procurement is a multidimensional decision. It involves considerations such as what type of movies ratings (for example, $G, P G$, PG-13, R, NC-17, NR) to play in the theaters in order to maintain competitive positioning appealing to the local audience and how far in advance to book the selected movies. The exhibitor's procurement strategy provides the basis for a macroscheduling plan; allocating the movies to 
different screens can then be managed adaptively as actual demand reveals itself.

To consider the first of these dimensions, Leenders and Eliashberg (2004) examined the commercial performance of locally rated movies in terms of their parental guidance in different countries. Taking an industry rather than a particular exhibitor's perspective, they considered the fact that the same movie often obtains different ratings in different countries. For example, the movie Godzilla was rated PG-13 in the United States, PG in Australia, and suitable for eleven years or older in Sweden. They analyzed the commercial performance of movies released by major studios in the United States in 1997 and 1998 and in foreign countries such as the United Kingdom, France, Germany, Sweden, Spain, and Italy. They found not only that the effect of a restrictive movie rating on commercial performance outside the United States may be less severe (that is, less negative), but also that it may even have a positive impact in more masculine countries (for example, Italy). For forecasting box-office tickets sales, see Sawhney and Eliashberg (1996).

Jones and Ritz (1991), interested in the exhibitors' adaptive behavior, have also taken an industry's perspective in their modeling of the interaction between demand for movies and shelf-space supply of screens. Their model incorporates the dynamic behavior of the "average" consumer and exhibitor, and it provides an analytical basis for the temporal behavior of movies and their corresponding screens. Another industry-level analysis has been conducted by Elberse and Eliashberg (2003). They study the extent to which exhibitors respond adaptively to the demand for movies in the United States as well as in foreign markets. Their empirical analyses reveal that variables such as movie attributes and advertising expenditures, which are typically assumed to influence audiences directly, mostly do so indirectly through their impact on exhibitors' screen allocations. They also found that the longer is the time lag between releases, the weaker is the relationship between the U.S. and foreign market performance-an effect that is mostly driven by exhibitors' screen allocations. Swami, Puterman, 


\section{Jehoshua Eliashberg}

Table 5.6: Data: Restricted consideration set (list of movies played at the theater on all six screens).

\begin{tabular}{ll}
\hline \hline 1. The Accused (TA) & 23. Major League (ML) \\
2. Batman (B) & 24. Miss Firecracker (MF) \\
3. Chances Are (CA) & 25. New York Stories (NYS) \\
4. Cookie (C) & 26. Night Game (NG) \\
5. Dangerous Liaisons (DL) & 27. A Nightmare on Elm Street V(NESS) \\
6. Dead-Bang (DB) & 28. No Holds Barred (NHB) \\
7. Dead Calm (DC) & 29. The Package (TP) \\
8. Dead Poets Society (DPS) & 30. Pet Sematary (PS) \\
9. Disorganized Crime (DC) & 31. Peter Pan (PP) \\
10. Earth Girls Are Easy (EGE) & 32. Pink Cadillac (PC) \\
11. For Queen and Country (FQC) & 33. Police Academy 6 (PA6) \\
12. Friday the 13th, Part VIII (FT8) & 34. Relentless (RL) \\
13. Heathers (H) & 35. Rude Awakening (RA) \\
14. Honey, I Shrunk the Kids (HISK) & 36. Scandal (SDL) \\
15. Indiana Jones and the Last Crusade (U) & 37. See No Evil, Hear No Evil (SNEHNE) \\
16. Lean On Me (LOM) & 38. See You in The Morning (SYM) \\
17. Lethal Weapon 2 (LW2) & 39. Sing (SING) \\
18. Let It Ride (LIR) & 40. Speed Zone (SZ) \\
19. Leviathan (LTHN) & 41. Star Trek V: The Final Frontier (ST5) \\
20. License To Kill (LTK) & 42. Turner and Hooch (TH) \\
21. Lock Up (LU) & 43. UHF \\
22. Lover Boy (LB) & \\
\hline
\end{tabular}

and Weinberg (2001) have demonstrated how an exhibitor's movie replacement problem under stochastic environment can be modeled as a Markovian decision process where the decision maker observes the system state and chooses a course of action. Their analyses show that two practical heuristics, presumably employed by some exhibitors, are markedly outperformed by the optimal policy.

Work related to macroscheduling of an individual exhibitor is exemplified in Swami, Eliashberg, and Weinberg (1999). They conducted an ex post analysis for a six-screen theater located in New York. In that analysis, the facility's profitability for movies playing in 1989, over a twentyseven week period, was analyzed based on publicly available data and 
The Film Exhibition Business: Critical Issues, Practice, and Research

\begin{tabular}{|c|c|c|c|c|c|c|}
\hline week Screen & 1 & 2 & 3 & 4 & 5 & 6 \\
\hline 1 & NYS & $\mathrm{CA}$ & $\mathrm{DL}$ & LOM & PA6 & LTHN \\
\hline 2 & NYS & $\mathrm{CA}$ & $\mathrm{DL}$ & LOM & $\overline{\mathrm{DB}}$ & LTHN \\
\hline 3 & $\mathrm{DL}$ & NYS & $C A$ & $\mathrm{H}$ & $\mathrm{DB}$ & SING \\
\hline 4 & $\overline{D L}$ & NYS & $\mathrm{ML}$ & $\mathrm{H}$ & $\overline{D C}$ & TA \\
\hline 5 & $D O C$ & $\mathrm{ML}$ & NYS & $\mathrm{H}$ & $D C$ & $T A$ \\
\hline 6 & SYM & $M L$ & DOC & PS & $\mathrm{SZ}$ & $\mathrm{H}$ \\
\hline 7 & SYM & LB & $M L$ & SDL & PS & $\mathrm{H}$ \\
\hline 8 & SYM & LB & $\mathrm{ML}$ & $S D L$ & PS & MF \\
\hline 9 & SNEHNE & EGE & $\overline{M L}$ & $\mathrm{SDL}$ & PS & $\mathrm{MF}$ \\
\hline 10 & SNEHNE & EGE & FOC & $\mathrm{SOL}$ & PS & MF \\
\hline 11 & EGE & $\mathrm{PC}$ & IJ & IJ & $\overline{S D L}$ & SNEHNE \\
\hline 12 & DPS & $\mathrm{NHB}$ & IJ & IJ & SNEHNE & $\mathrm{PC}$ \\
\hline 13 & DPS & ST5 & ST5 & IJ & IJ & SNEHNE \\
\hline 14 & DPS & ST5 & ST5 & IJ & $\mathrm{IJ}$ & SNEHNE \\
\hline 15 & IJ & ST5 & DPS & 8 & $B$ & HISK \\
\hline 16 & IJ & ST5 & DPS & $B$ & $B$ & HISK \\
\hline 17 & IJ & $L W 2$ & DPS & $B$ & $B$ & HISK \\
\hline 18 & LTK & LW2 & $B$ & IJ & PP & HISK \\
\hline 19 & LTK & $L W 2$ & $B$ & $\mathrm{IJ}$ & $\mathrm{UHF}$ & HISK \\
\hline 20 & LTK & LW2 & $B$ & $\mathrm{TH}$ & FT8 & HISK \\
\hline 21 & LTK & LW2 & $B$ & $\mathrm{TH}$ & FT8 & LU \\
\hline 22 & LTK & $\mathrm{LU}$ & $\bar{B}$ & $\mathrm{TH}$ & FT8 & NES5 \\
\hline 23 & $\mathrm{RA}$ & $L R$ & $B$ & LU & LW2 & NES5 \\
\hline 24 & LR & $T P$ & B & $\mathrm{LU}$ & LW2 & $C$ \\
\hline 25 & DPS & $T P$ & $B$ & $\overline{R L}$ & LW2 & C \\
\hline 26 & DPS & TP & $B$ & $\mathrm{RL}$ & $L W 2$ & C \\
\hline 27 & $R L$ & TP & $B$ & $\mathrm{C}$ & LW2 & $\mathrm{NG}$ \\
\hline
\end{tabular}

Figure 5.5: Actual schedule of movies at a NYC theater.

under several assumptions concerning house allowance, sliding shares, and concession profits (see Table 5.6 and Figure 5.5 for the actual set of movies the theater chose to play during the time period of interest). The set of movies actually selected by the theater for running is called the restricted considerations set. An integer programming-based model (SILVERSCREENER) has been developed and applied to assess the potential for profitability improvement. Figure 5.6 shows the optimal schedule the model recommended. The optimality (net contribution from tickets and concession sales) is taken from the exhibitor's perspective and it considers explicitly the fact that the longer the movie is playing, the larger is the exhibitor's share of the box-office grosses. (The movie NYS [ New York Stories], for instance, actually played for five weeks whereas the model 


\section{Jehoshua Eliashberg}

\begin{tabular}{|c|c|c|c|c|c|c|}
\hline WeEk Bereer & 1 & 2 & 3 & 4 & 5 & 6 \\
\hline 1 & NYS & $\mathrm{CA}$ & $\overline{[L L}$ & LOM & PA6 & LTHN \\
\hline 2 & NYS & $\overline{C A}$ & $\overline{\mathrm{DL}}$ & LOM & $\mathrm{DB}$ & LTHN \\
\hline 3 & NYS & $\mathrm{H}$ & $\overline{D L}$ & LOM & $\mathrm{DB}$ & LTHN \\
\hline 4 & NYS & $\mathrm{H}$ & $\mathrm{TA}$ & LOM & $D C$ & $\mathrm{ML}$ \\
\hline 5 & NYS & $\bar{H}$ & $T A$ & LOM & $D C$ & ML \\
\hline 6 & NYS & $\mathrm{H}$ & TA & LOM & PS & $M L$ \\
\hline 7 & NYS & $\mathrm{H}$ & $\mathrm{MF}$ & SDL & PS & $\mathrm{ML}$ \\
\hline 8 & NYS & $\mathrm{H}$ & $\mathrm{MF}$ & SDL & $\mathrm{PS}$ & $M L$ \\
\hline 9 & NYS & $\mathrm{H}$ & $\mathrm{MF}$ & SDL & SYM & SNEHNE \\
\hline 10 & NYS & $\mathrm{H}$ & EGE & SDL & SYM & SNEHNE \\
\hline 11 & IJ & $\mathrm{H}$ & EGE & SDL & $1 \mathrm{~J}$ & SNEHNE \\
\hline 12 & I.J & $\mathrm{H}$ & $E G E$ & DPS & 1.5 & SNEHNE \\
\hline 13 & I.J & ST5 & $\mathrm{EGE}$ & $\mathrm{DPS}$ & 1.] & ST5 \\
\hline 14 & I.] & ST5 & EGE & DPS & 1.1 & ST5 \\
\hline 15 & I.J & HISK & $B$ & DPS & I. & $B$ \\
\hline 16 & $1 . J$ & HISK & $B$ & DPS & 1.1 & $B$ \\
\hline 17 & $1 \mathrm{~W} 2$ & HISK & $B$ & DPS & 11 & $B$ \\
\hline 18 & LW2 & LTK & $B$ & $D P S$ & 1.1 & $B$ \\
\hline 19 & LW2 & LTK & $B$ & DPS & ل & $B$ \\
\hline 20 & IW/2 & $L T K$ & $\mathrm{~B}$ & DPS & $\mathrm{TH}$ & $B$ \\
\hline 21 & $\operatorname{LM} 2$ & LIK & $B$ & DPS & $\mathrm{TH}$ & $B$ \\
\hline 22 & LWO2 & NES5 & $B$ & DPS & $\mathrm{IH}$ & $B$ \\
\hline 23 & $1 \mathrm{~W} 2$ & NES5 & $B$ & DPS & IH & $B$ \\
\hline 24 & 1102 & $c$ & TP & DPS & $\mathrm{IH}$ & $B$ \\
\hline 25 & $1 \mathrm{NO}$ & $c$ & $T P$ & DPS & $\mathrm{TH}$ & $\mathrm{B}$ \\
\hline 26 & 1102 & 111 & IP & DPS & $\mathrm{TH}$ & $B$ \\
\hline 27 & LW2 & $\mathrm{LU}$ & $T P$ & DPS & $\mathrm{TH}$ & $B$ \\
\hline
\end{tabular}

Figure 5.6: Optimal schedule generated by SCREENER-I (ex-post) (for the restricted consideration case).

recommended it should have played for ten weeks.) Clearly, there was money left on the table. The exhibitor could have increased the theater's profitability by 38 percent by running fewer movies for a longer period of time (Table 5.7). The tendency to actually play more movies for a shorter time period may be explained by the pressure the distributors put on the exhibitor. The room for profitability improvement gets even larger when the exhibitor is allowed to procure movies from a larger (expanded) set of movies running elsewhere in the country over the same twenty-seven week period (Table 5.8). In that case, the profitability could have gone up by 121 percent (Table 5.9). The SilverScreener model has been implemented by an exhibition circuit in Europe, first for a single facility and 
The Film Exhibition Business: Critical Issues, Practice, and Research

Table 5.7: Potential for improving cumulative profit to the exhibitor: "Money left on the table" for the restricted set case.

\begin{tabular}{ll}
\hline \hline Estimated actual profit: & $\$ 585,175$ \\
Number of different movies: & 43 \\
Estimated profit (restricted set): & $\$ 805,988$ \\
Number of different movies: & 27 \\
Profitability improvement: & $38 \%$ \\
\hline
\end{tabular}

Table 5.8: Expanded consideration set (movies played at NYC theater and other movies played elsewhere during the same period).

\begin{tabular}{ll}
\hline 44. The Abyss (TAB) & 66. Miracle Mile (MM) \\
45. Adventures of Baron Munchausen (ABM) & 67. Parenthood (PH) \\
46. Adventures of Milo \& Otis (AMO) & 68. Rain Man (RM) \\
47. Bill and Ted's Excellent Adventure (BTA) & 69. Red Scorpion (RS) \\
48. Casualties of War (COW) & 70. Renegades (RG) \\
49. Cheetah (CH) & 71. The Rescuers (TR) \\
50. Cousins (CSN) & 72. Road House (RH) \\
51. Criminal Law (CL) & 73. Rood Tops (RT) \\
52. Cyborg (CBRG) & 74. Say Anything (SA) \\
53. The Dream Team (TDT) & 75. Sea of Love (SOL) \\
54. Do the Right Thing (DRT) & 76. Sex, Lies and Videotape (SLV) \\
55. Field of Dreams (FD) & 77. Shag (SHAG) \\
56. Fletch Lives (FL) & 78. She's Out of Control (SOC) \\
57. Ghostbusters II (GB2) & 79. Skin Deep (SD) \\
58. Great Balls of Fire (GBOF) & 80. Troop Beverly Hills (TBH) \\
59. The Horror Show (THS) & 81. Uncle Buck (UB) \\
60. How I Got into College (HGC) & 82. Weekend at Bernie's (WB) \\
61. K-9 & 83. When Harry Met Sally (WHMS) \\
62. The Karate Kid III (KK3) & 84. Winter People (WI) \\
63. Kick Boxer (KB) & 85. Wired (WIRED) \\
64. Listen to Me (LTM) & 86. Working Girl (WG) \\
65. Lost Angels (LA) & 87. Young Einstein (YL) \\
\end{tabular}


Table 5.9: Potential for improving cumulative profit to the exhibitor: "Money left on the table" for the expanded set case

\begin{tabular}{ll}
\hline \hline Estimated actual profit: & $\$ 585,175$ \\
Number of different movies: & 43 \\
Estimated profit (expanded set) & $\$ 1,294,408$ \\
Number of different movies: & 25 \\
Profitability improvement: & $121 \%$ \\
\hline
\end{tabular}

later for multiple facilities, each having multiple screens, in the same city (Eliashberg, Swami, Weinberg, and Wierenga, 2001). The results indicate actual improvement in the exhibitor's profitability compared to a control group.

Situations where the analysis takes the viewpoint of the movie's exhibitor and its distributor simultaneously have also been studied. Such a situation is described in Eliashberg, Jonker, Sawhney, and Wierenga (2000). A pre-release forecasting and diagnostic decision support system, MOVIEMOD, has been developed and implemented in Europe. The implementation evaluated media (advertising) and distribution (weekly screens allocation) plans for the movie Shadow Conspiracy and led to modification of the plans and, consequently, to an improved performance.

\section{SUMMARY AND OPPORTUNITIES FOR FURTHER RESEARCH}

It is encouraging to observe that some research has been conducted with respect to various critical exhibition-business-related issues. This research has already made some and is likely to make even more of an impact in the future of the exhibition business. However, there still remain a number of open questions that provide opportunities for further research.

I am not aware of any rigorous research that takes an industry perspective and addresses the important questions: What is the nature of the 
power structure in the industry? How has it changed over time? What are its key determinants? What role will art houses play in the future? What differences, if any, should be included in contracts signed with art-house exhibitors?

The contracting terms of producers, actors, and other members of the creative community have already received some research attention via the principal-agent framework (Chisholm 1997) and other frameworks (Weinstein 1998). Surprisingly, however, not much has been done with respect to the exhibitor-distributor contractual relationship. This also represents a promising area for further research.

The digitalization phenomenon offers a number of interesting opportunities for research, including identifying potential pirates of intellectual properties such as movies; understanding their motivation; analyzing consumers with respect to the extent to which they notice, appreciate, and are willing to pay for the incremental benefits of a digital versus analogue entertainment experience; and predicting and controlling the diffusion of digital exhibition. With regard to the first two questions, research related to the personality characteristics (Wagner and Sanders 2001) and the national culture (Husted 2000) of software pirates might be helpful. Other open questions concerning the digital projection include: How will it change the distributor-exhibitor relationship? The contractual arrangement? What theater size and other economies of scale justify the investment in the infrastructure? How will it affect the exhibitor's control over screens allocation? Operational efficiency?

Is there room for additional profitability improvement by microscheduling the movies already selected for the theater? The microscheduling problem involves modeling the performance of movies within any given day of the week. This requires recognizing various constraints such as no two different movies starting at the same time (to minimize lobby congestion and smooth out concession labor), the minimum time between showings needed to make the screening room ready, and the 


\section{Jehoshua Eliashberg}

opening/closing hours of the facility. Work by Eliashberg, Miller, Swami, Weinberg, and Wierenga (2003) has already begun in this direction.

The increased level of exhibition concentration and the appearance of new players also raise a number of important research issues such as development of differentiation strategies and managing a portfolio of entertainment assets and businesses. In a related vein, segmenting consumers based on their movie decision-making processes and analyzing the effectiveness of various consumer-relationship management strategies in the context of movie going are other areas, worth formal research.

\section{REPERENCES}

Battaglio, Stephen, and Kirk Honeycutt. 1998. "Bronfman: Event Films Need Event Ticket Prices," Hollywood Reporter, April 1.

Brasell, R. Bruce. 1999. "Movie Exhibition Monopoly in Mobile No More: Diversity in Films Screened Promised," The Harbinger (Mobile, Alabama), February 23.

British Film Institute. "UK Box Office Breakdown 1995-2002." (Accessed from http:www.bfi.org.uk/facts/stats/index.html on 8/19/04.)

Caves, Richard E. 2000. Creative Industries: Contracts between Art and Commerce, Cambridge, MA: Harvard University Press.

Chisholm, Darlene C. 1997. "Profit-Sharing Versus Fixed-Payment Contracts: Evidence from the Motion Picture Industry," Journal of Law, Economics \& Organization, 13(1): 169-201.

Credit Suisse First Boston. 2002. "Digital Cinema: Episode II," Sector Review: Americas/United States Imaging Technology, June 4. (Accessed from http://www.sabucat.com/digital.pdf on 3/28/04.)

Daniels, Bill, David Leedy, and Steven D. Sills. 1998. Movie Money: Understanding Hollywood's (Creative) Accounting Practices, Los Angeles, CA: Silman-James Press.

Davis, Peter. 2001. "Spatial Competition in Retail Markets: Movie Theaters," unpublished manuscript, Economics Department, London School of Economics, December.

- 2003a. "The Effect of Local Competition on Retail Prices: The U.S. Motion Picture Exhibition Market," unpublished manuscript, Economics Department, London School of Economics, September. 
2003b. "Fine Young Cannibals in the U.S. Motion Picture Exhibition Market," unpublished manuscript, Economics Department, London School of Economics, October.

Diorio, Carl. 2003. "Regal Pumped for Hoyts' Haul," Variety, February 4.

Doyle, Barry. (1998). "Return of the Super Cinema (United Kingdom)," History Today, 48, February 1, pp. 2-4.

EAO (European Audiovisual Observatory). 2002. Focus 2002: World Market Film Trends. (Accessed from http://www.obs.coe.int/oea.publ/market/focus.html on $3 / 28 / 04$.)

Einav, Liran, and Barak Y. Orbach. 2001. "Uniform Prices for Differentiated Goods: The Case of the Movie-Theater Industry," Harvard Olin Discussion Paper No. 337, October.

Elberse, Anita, and Jehoshua Eliashberg. 2003. "Demand and Supply for Sequentially Released Products in International Markets: The Case of Motion Pictures," Marketing Science, 22(3): 329-54.

Eliashberg, Jehoshua, Sanjeev Swami, Charles B. Weinberg, and Berend Wierenga. 2001. "Implementing and Evaluating SilverSCreener: A Marketing Management Support System for Movie Exhibitors," Interfaces, 31(3), Part 2 of 2, May-June, pp. S108-27.

Eliashberg, Jehoshua, Jedid-Jah Jonker, Mohanbir S. Sawhney, and Berend Wierenga. 2000. "Moviemod: An Implementable Decision Support System for Pre-Release Market Evaluation of Motion Pictures," Marketing Science, 19(3): 226-43.

Eliashberg, Jehoshua, Steven J. Miller, Sanjeev Swami, Charles B. Weinberg, and Berend Wierenga. 2003. "Marketing Models for Movie Managers: Model Development and Implementation Experience," Marketing Science Conference, University of Maryland, June.

Eller, Claudia. 2002. "Showtime for Theater Owners: More Americans Went to Movies This Year than Anytime since 1959," Los Angeles Times, December 26.

Emmons, Natasha. 2001. "Game Works Enters Movie Theater Biz," Amusement Business, May 28.

Hanssen, Andrew F. 2002. "The Block-Booking of Films: A Re-Examination," Journal of Law and Economic, 43 (October): 395-426.

Hiltbrand, David. 2003. "TV Ads Play on the Big Screen," Philadelphia Inquirer, February 2.

Husted, Bryan W. 2000. "The Impact of National Culture on Software Piracy," Journal of Business Ethics, 26: 197-211. 


\section{Jehoshua Eliashberg}

Jones, J. Morgan, and Christopher J. Ritz. 1991. "Incorporating Distribution into New Product Diffusion Models," International Journal of Research in Marketing, 8 (June): 91-112.

Leenders, Mark A.A.M. and Jehoshua Eliashberg. 2004. "Antecedents and Consequences of Third-Party Products Evaluation Systems: Lessons from the International Motion Picture Industry," unpublished manuscript, Marketing Department, University of Pennsylvania Wharton School of Business.

Media Force. 2001. "Ten Top Pirated Movies in August [2001]," September 24. (Accessed from http://www.afterdawn.com/news/archive/2347.cfm on 3/28/04.)

Motion Picture Association of America website: http://www.mpaa.org

Sawhney, Mohanbir S., and Jehoshua Eliashberg. 1996. "A Parsimonious Model for Forecasting Gross Box-Office Revenues of Motion Pictures," Marketing Science, 15(2): 113-31.

Screen Digest. 2001. "Report on the Implications of Digital Technology for the Film Industry," UK, Department for Culture. Media and Sport, Creative Industries Division.

Screen Digest Report. 2002. "On the Implications of Digital Technology for the Film Industry," September. (Accessed from http://www.culture.gov.uk/ PDF/Screen_Digest_Report.pdf on 3/28/04.)

Stigler, George. 1968. "A Note on Block-Booking," The Organization of Industry, Irwin Publishing Co.

Swami, Sanjeev, Jehoshua Eliashberg, and Charles B. Weinberg. 1999. "SilverScreener: A Modeling Approach to Movie Screens Management," Marketing Science, 18(3): 352-72.

Swami, Sanjeev, Martin L. Puterman, and Charles B. Weinberg. 2001. "Play It Again, Sam? Optimal Replacement Policies for Motion Picture Retailing," Manufacturing and Services Operations Management, 3(4): 369-86.

Towira, Pimpaka. 2000. "Saturday Night at the Movies," The Nation (Thailand), July 18.

Valenti, Jack. 2001. "Valenti Warns of Potentially Devastating Economic Impact of Copyright Theft," MPAA press release, April 3. (Accessed from http://www.mpaa.org/jack/2001/2001_04_03a.htm on 3/28/04)

Vogel, Harold L. 2001. Entertainment Industry Economics: A Guide for Financial Analysis, Cambridge, UK, Cambridge University Press.

Wagner, Suzanne, C., and G. Lawrence Sanders. 2001. "Considerations in Ethical Decision-Making and Software Piracy," Journal of Business Ethics, 29: 161-67. Weinstein, Mark. 1998. "Profit-Sharing Contracts in Hollywood: Evolution and Analysis," Journal of Legal Studies, January: 67-112. 


\title{
A Concise Handbook of
}

\section{Movie Industry Economics}

\author{
Edited by
}

CHARLES C. MOUL

Washington University in St. Louis 
CAMBRIDGE UNIVERSITY PRESS

Cambridge, New York, Melbourne, Madrid, Cape Town, Singapore, São Paulo

Cambridge University Press

40 West 20th Street, New York, NY 10011-4211, USA

www.cambridge.org

Information on this title: www.cambridge.org/9780521843843

(C) Cambridge University Press 2005

This book is in copyright. Subject to statutory exception and to the provisions of relevant collective licensing agreements, no reproduction of any part may take place without the witten permission of Cambridge University Press.

First published 2005

Printed in the United States of America

A catalog record for this book is available from the British Library.

Library of Congress Cataloging in Publication Data

A concise handbook of movie industry economics / edited by Charles C. Moul.

p. $\mathrm{cm}$.

Includes bibliographical references and index.

ISBN 0-521-84384-7

1. Motion picture industry-Economic aspects - United States. I. Moul, Charles C., 1972-

$$
\begin{array}{cl}
\text { PN1993.5.U6S493 } & 2005 \\
384^{\prime} .83^{\prime} 0973-\mathrm{dc} 22 & 2004051993
\end{array}
$$

ISBN-13 978-0-521-84384-3 hardback ISBN-10 0-521-84384-7 hardback

Cambridge University Press has no responsibility for the persistence or accuracy of URLs for external or third-party Internet Web sites referred to in this book and does not guarantee that any content on such Web sites is, or will remain, accurate or appropriate.

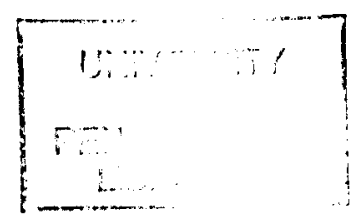




\section{Contents}

1 Critiquing Hollywood: The Political Economy of Motion Pictures

Janet Wasko

2 Film Production in the Digital Age - What Do We Know about the Past and the Future?

S. Abraham Ravid

3 Movie Industry Accounting

Harold L. Vogel

4 Theatrical Release and the Launching of Motion Pictures Charles C. Moul and Steven M. Shugan

5 The Film Exhibition Business: Critical Issues, Practice, and Research

Jehoshua Eliashberg 